\title{
Valley of the unicorns: consumer genomics, venture capital and digital disruption
}

Stuart Hogarth, Department of Sociology, University of Cambridge.

Email: sh339@cam.ac.uk

Forthcoming in New Genetics and Society (special issue on consumer genomics edited by Stuart Hogarth and Paula Saukko). Accepted for publication 29 Jun 2017

\begin{abstract}
Drawing on the sociology of expectations and sociology of conventions, this paper explores issues of worth and value in the bioeconomy, and the promissory character of contemporary capitalism. Arguing that the literature on biocapital has paid insufficient attention to geographical differentiation in capital accumulation strategies, this paper situates the consumer genomics firm 23andme in the entrepreneurial culture of Silicon Valley. The paper suggests that in Silicon Valley the relationship between moral worth and economic value is mediated through the concept of disruptive innovation, which functions as both ideological construct and a set of commercial practices utilised by the founders of start-up firms and the venture capitalists who invest in them. Analysing 23andme's status as a 'unicorn' firm, the paper describes how the recent increase in private investment capital in Silicon Valley has led to a new model of business development for start-ups and considers its implications for corporate governance.
\end{abstract}

\section{Keywords}

Consumer genomics, disruptive innovation, venture capital, FDA, 23andme, Silicon Valley. 


\section{Introduction}

In 2007 the Silicon Valley consumer genomics firm 23andme launched with a bold mission to revolutionise healthcare and biomedical research. From the outset the firm's ambitions were global in scale: co-founder Anne Wojicki declared that 23andme aimed to become "the world's trusted source of personal genetic information" (23andme 2008). These grand ambitions were underpinned by investment funding from leading players in Silicon Valley, each of them global leaders in their respective sectors: the venture capital firm New Enterprise Associates, the biopharmaceutical firm Genentech, and the internet search firm Google. Like other start-up firms (including its rivals in the nascent consumer genomics market), 23andme was heavily dependent on continued injections of private capital as it sought to build a market for its products and services, and measured by the amount of private capital the firm has raised, 23andme has been highly successful. It raised $\$ 240 \mathrm{M}$ in a series of five financing rounds between 2007 and 2015 (see table 1), and by 2015 had achieved 'unicorn' status, a term used to describe privately-held firms valued at over $\$ 1$ Billion. To put this achievement in perspective, of the 22 diagnostics firms listed on the NASDAQ only two raised more than $\$ 100 \mathrm{M}$ when they floated as public companies, i.e. 23andme has raised more money in the private capital markets than its counterparts have been able to raise by going public.

This financial success was achieved despite longstanding uncertainty about the firm's commercial viability, public controversy about the ethics of consumer genomics, professional critique of the scientific validity of genetic risk scores offered by the firm (and its rivals) (Mihaescu et al. 2009), and then regulatory censure by the US government. The US Food and Drug Administration (FDA) closed down the health-related aspects of 23andme's business in 2013 (see Curnutte, M this issue). Two years later, when the FDA took regulatory action against Theranos, another high-profile Silicon Valley diagnostics firm, some media commentators suggested that the regulatory problems encountered by the two firms exemplified a broader crisis in the corporate culture of Silicon Valley. These critics pointed to failures in corporate governance, media complicity in promotional hype and a lack of due diligence on the part of investors, all fuelling a dangerous new investment bubble underpinned by the ideology of disruptive innovation (McDermid 2016).

How to explain 23andme's success in attracting financial investment despite the seemingly toxic combination of commercial underperformance and regulatory scandal? Given the importance of personal networks in securing VC finance, it was helpful that 23andme was, from the outset, enmeshed in the Silicon Valley establishment, most notably through co-founder (and current CEO) Anne Wojcicki's marriage to Sergey Brin, the co-founder of Google. Google invested \$3.9M in Series A and then $\$ 2.6 \mathrm{M}$ in Series B, but in addition Brin provided a start-up loan of $\$ 2.6 \mathrm{M}$ ahead of the Series A round, and a further $\$ 10 \mathrm{M}$ ahead of the Series B financing round (Rao 2009). However, the power of personal networks is not the focus of this paper, which is concerned instead with issues of worth and value in the bioeconomy, and what Paul Martin (2015) has called "the promissory character of contemporary capitalism". This paper suggests that in Silicon Valley the relationship between moral worth and economic value is mediated through the concept of disruptive innovation, which functions as both ideological construct and a set of commercial practices utilised by the founders of start-up firms and the venture capitalists who invest in them. 
In addressing matters of political economy, this paper takes an approach hitherto neglected in the literature on consumer genomics, a puzzling oversight given that in recent years a growing body of scholarly work has argued that the emergence of commercial biotechnology has generated a new form of capitalism: biocapitalism (for an overview of this literature, see Helmreich 2008). Attempts to characterize a distinct form of biocapital are consistent with a long tradition of middle-range theory in political economy that addresses the "specific forms and mediations of capitalist processes, such as the nature of institutions, or new forms of organization such as post-Fordism." (Sayer 1995, p10). This paper offers two original contributions to the scholarship on biocapital. Firstly, by suggesting that as an attempt to understand sectoral differentiation, this literature has been too ready to generalize using data on the biotech therapeutics sector and has failed to understand the distinctive dynamics of the diagnostics sector. However, its more substantive contribution is to argue for a greater focus on geographical rather than sectoral differentiation (Sheppard 2013). I locate 23andme in its geographical setting of Silicon Valley, identifying the ways in which firm might be characterized as typical of the distinctive local culture of entrepreneurialism that has developed in the area since the 1980s.

I begin by situating this paper's conceptual framework in the broader social science literature about the bioeconomy. By way of descriptive context, I then outline the role of venture capital in the financing of high-technology start-ups, the growth of Silicon Valley as a geographic cluster for high-tech firms and the key features of Silicon Valley disruption. I then move on to describe how 23 andme modelled itself as a disruptive firm and to discuss how that strategy may have helped attract investment funding.

\section{Table one}

\section{3andme funding rounds 2007-15 Total raised $\$ 240.92 \mathrm{M}$}

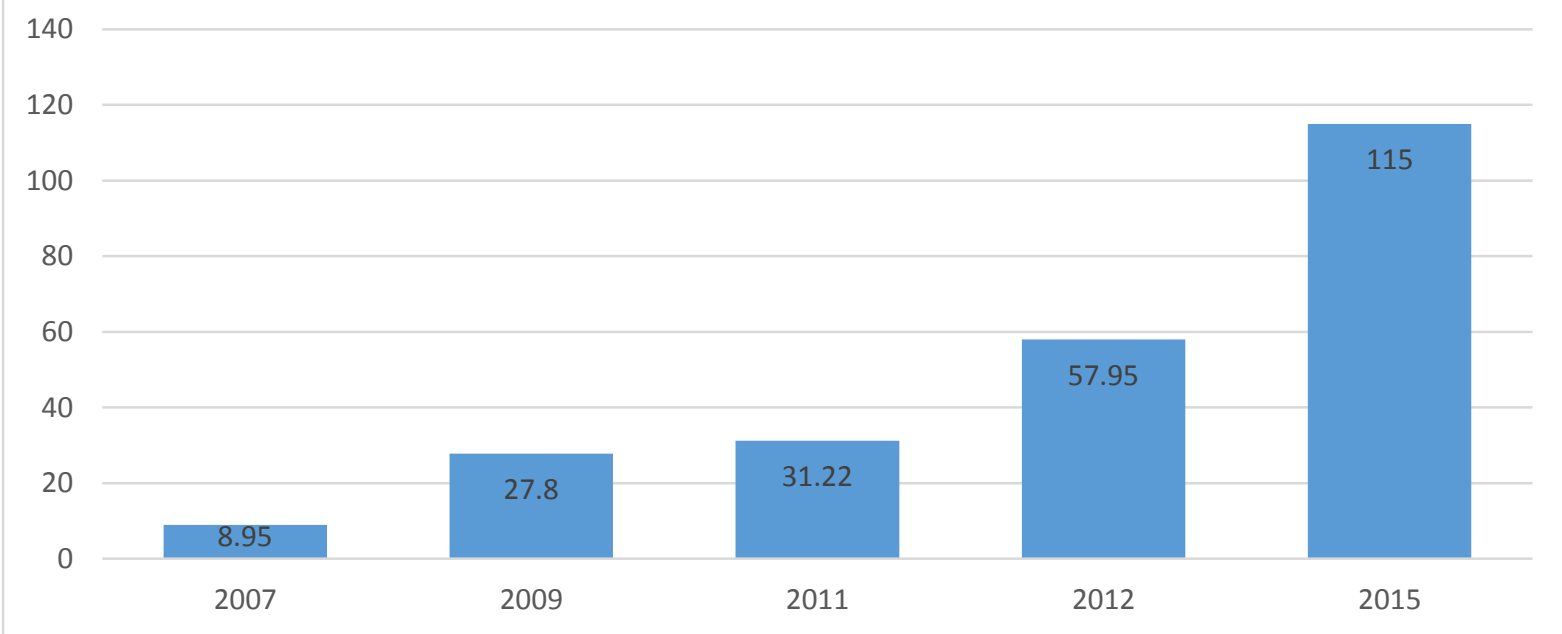

Data source: CrunchBase

\section{Conceptual framework}

In addressing venture capital's role in consumer genomics, this paper is a contribution to a small body of work in critical political economy that has explored the relationship between financialisation and the biotechnology sector. The bioeconomy has been described as a Ponzi scheme (Mirowski 2011), a boondoggle (Lazonick and Tulum 2011), and a sector "underpinned 
by a rentier regime in which financial asset values are more important than revenues from the sale of biotechnology commodities" (Birch and Tyfield 2012). These papers share a common interest in understanding biotechnology as just one example of an industrial sector where financialisation is reshaping capitalist accumulation strategies. However, Birch and Tyfield went further by offering a critique of scholarship that has sought to characterize biocapital as a distinct new form of capitalism. Offering critical support to Birch and Tyfield's argument, Paul Martin (2015) has sought to extend his work on the sociology of expectations by exploring how "the promissory is transformed into the real and the role of VCs, market analysts and public exchanges in this process" (440).

Martin draws on the argument advanced by Moreira and Palladino (2005) that in contemporary biomedicine the subjectivity of the patient is "shaped by two, seemingly incommensurable, organizational logics, the 'regime of truth' and 'the regime of hope'" (55). Martin adopts this dual regime framework but shifts the unit of analysis from the self to the firm. Drawing on his survey of the emergent neurotech sector, he describes how start-up firms transition from a regime of hope to a regime of truth. Martin distinguishes between start-up firms "who have no products on the market or in late stage development, and are poorly integrated into the pharmaceutical industry." Such firms belong to the "'regime of hope' ... a speculative market based on promissory assets that cannot be traded in any established market" (434). Martin contrasts this group with a second set of firms which have "products on the market, significant sales and profits, a relatively large number of products in late stage development and who are well-integrated into the pharmaceutical industry" (437.) These firms belong to a "regime of truth' ... belonging to a real economy with tangible assets that are traded in established financial and technology markets" (437). Start-up firms begin in the regime of hope, and then, in the course of developing and bringing to market a portfolio of products, they move into the regime of truth. Although firms transition from the regime of hope to the regime of truth, the two regimes are "linked and entangled" and some firms "occupy intermediary positions between them" (437). In this paper I suggest that unicorn firms like 23andme are located in this liminal space straddling the regimes of hope and truth, and that the growing number of unicorns signals an expansion in the capacity of this liminal space.

By focusing on the political economy of biotech commercialization and the dynamics of firm development, Martin expands the institutional complexity of the regime of truth. Moreira and Palladino focused on the evaluation of clinical trial data by regulatory agencies and Health Technology Assessment bodies but Martin's truth regime encompasses a variety of other actors, domains and evaluative mechanisms such as the consumer market and the financial markets that trade shares in public firms. Flotation as a public company through an initial Public Offering (IPO) is a critical entry point into a regime of truth in which information about the firm's financial performance, revenue streams, profits and share price become public knowledge and subject to critical scrutiny by market analysts.

This paper seeks to build on Martin's account by addressing some potential weaknesses in his conceptual framework. Firstly, the dichotomy between regimes of hope and truth rests on a characterization of public stock markets as governed by the rational calculation of value, thus ignoring the vulnerability of institutional investors to the irrational exuberance of technology bubbles. Similarly, its characterization of the valuation process used by angel and venture investors is limited to describing "various options-based valuation models and judgements 
about the quality of management" (438). This is inconsistent with Martin's characterization of these investors as part of the regime of hope because it downplays the extent to which a range of non-financial values help to establish the worth of a firm at this early stage in its development.

To understand the values and valuation processes that underpin the practice of disruptive innovation, I draw on David Stark's (2009) work on innovation and entrepreneurship, in which he explores the "evaluative principles" that determine how worth/value is established in the contemporary economy and in particular, how moral judgments and rational calculations of economic value are interpenetrated. His concept of evaluative principles is an elaboration of the sociology of conventions framework developed by Boltanski and Thévenot (1991) that describes how multiple "orders of worth" operate within a single social domain. Stark defines entrepreneurship as "the ability to keep multiple evaluative principles in play and to exploit the resulting friction of their interplay" (6).

A second problem with Martin's framework is that its model of how firm growth, product development, and financial investment are interlinked is based on the biopharmaceutical sector, and pays no attention to the diagnostics sector. The development of novel therapeutics proceeds along a well-defined sequential pathway of pre-clinical and clinical phases of development and, as Martin explains, progress through these stages provides crucial signals to investors that may trigger new funding rounds, public flotation or even firm acquisition. However, diagnostics firms face lower regulatory hurdles and have products on the market far faster than therapeutics firms, and their product development process has no equivalent formal regulatory definition of pre-clinical/clinical development stages. This has implications for the transition from the regime of hope to the regime of truth - diagnostics firms generally float on a public stock market at a point when they are already selling products, whereas for therapeutics firms it is sufficient to have moved a candidate drug through the first stages of clinical development.

Martin's focus on therapeutic rather than diagnostic innovation is replicated in the broader literature on biotech finance referenced earlier. By redressing this imbalance, this paper offers new insights into the political economy of biomedical innovation. Moreover, by characterizing 23andme as a Silicon Valley start-up, the paper will offer a different approach to understanding the bioeconomy, by locating firms in geographical, as well as sectoral context. Such an approach draws on a rich tradition of scholarship in political economy that seeks to understand how capitalism is socially embedded as a moral economy, and to delineate the variety of forms that capitalism in different locales, "distinguished partly according to their cultural legacies and forms of embedding" (Sayer 2004).

\section{The regime of venture capital}

A critical dimension of 23andme's embedding in Silicon Valley entrepreneurial culture is the firm's relationship to venture capital investors. High-tech start-up firms require support from investors as they move from R\&D to commercialisation of products. Investment proceeds through a series of stages with initial investments from family, friends or angel investors and subsequent funding generally coming from venture capital (VC) firms or through commercial alliances with larger firms (the latter is a common pattern in the biopharmaceutical sector). Inadequate finance is a common cause of firm failure and US firms enjoy a competitive 
advantage as a consequence of the much larger domestic VC sector, for instance US biopharmaceutical firms generally receive far larger VC investments than their European rivals (Hogarth and Salter 2010). Venture capitalists are active investors providing guidance to the firms they invest in, often taking a position on the board and exercising authority in key decisions such as the composition of the senior management team, bringing in new executives or removing some of the original start-up founders.

Venture capitalists hope for a return of investment (ROI) of between 500-1,000\% within five years, but they know that around one-third of investments will make no return at all, and a further third only a modest ROI. When investors evaluate a start-up firm, they need to assess three key areas: the science/technology, the business model and the management team. Weakness in any one of these areas could have a negative impact on the potential for a significant return on investment (Shapin 2008).

There are well-established financial techniques that investors can use as part of the due diligence process when evaluating a prospective firm's business model, including some that are specific to the biotech sector (Keegan 2008), but a recent survey of VC firms (Gompers et al 2016) found that almost half often make investment decisions based on gut instinct and that $17 \%$ of early-stage investors use no financial metrics. Such speculative valuation practices, reliant on tacit knowledge, hunches and the VC's instinctive 'feel for the game' are integral to VC operations in Silicon Valley (Shapin 2008), and the area is thus fertile ground for the growth of what Martin terms promissory capitalism.

\section{Valley values and the corruption of disruption}

Silicon Valley is the name given to the southern region of the San Francisco Bay Area that became the base for the US semiconductor industry in the early 1970s, and has subsequently established a global reputation as the spiritual home of high-tech entrepreneurship. It remains a major centre for the US computer hardware industry, including giant multinational corporations like Apple, but its growth has been driven by diversification: the 1980s saw the emergence of leading biopharmaceutical firms such as Genentech, and in the 1990s dotcomboom, software firms like Google. Silicon Valley thus boasts a world-leading position in the two pillars of the contemporary knowledge-based economy: information technology and biotechnology.

Policymakers across the globe who aspire to compete in the knowledge-based economy have looked to Silicon Valley as a model and have sought to emulate this innovation eco-system (Casper 2006). The organisational infrastructure that provides the region's competitive advantage is multi-faceted, including generous state funding, leading higher education institutions, and a strong private capital market.

The Valley is home to a panoply of large venture capital (VC) firms like Mohr Davidow whose growth since the 1970s has been bound up with that of the high-tech firms they have supported with private capital and strategic guidance. Silicon Valley is the centre of US venture capital nearly $50 \%$ of all US VC investments are tied up in the area's firms (Gupta and Wang 2016). However, traditional VC firms are no longer the only investors powering the growth of Silicon Valley start-ups: successful dotcom entrepreneurs like Elon Musk and Peter Thiel have put their money to work by diversifying into venture capital. Google Ventures (GV) exemplifies this trend. 
Established by the search engine firm in 2009 , GV has $\$ 2$ billion under management and in 2012 it increased its annual investment to $\$ 300 \mathrm{M}$.

The massive growth in private capital has led to a new model of business development for hightech start-ups in Silicon Valley. Traditionally, start-ups have used private finance as a staging post on the path to flotation as a public company, but a growing number of firms are now existing indefinitely supported by private finance. The most successful of these firms are socalled unicorns - firms that have yet to float as public companies but that are already valued at over \$1Bn. Unicorns are a predominantly US phenomenon - $64 \%$ of them are US-based - and they are most commonly found in Silicon Valley - 39\% of the world's unicorns are located there (Tellis 2016).

Venture capitalists may also be operating with a different business model. A report on the unicorn phenomenon by SharesPost (2016) describes how VC firms used to operate on the basis that one-third of firms would provide no ROI, another third would only return the initial investment and the remaining third would provide the real profit for the VCs. However, in the new model a small proportion, perhaps $2 \%$ of firms, will provide the bulk of the profit, the true "home runs". Significantly for our interest in processes of valuation and worth, it is precisely in relation to these potential "home run" investments that established techniques for calculating the potential ROI are least useful.

Demand for a radically new innovation can only be perceived demand; market surveys and statistics of projected consumption are 'images' or 'visions' (or 'forecasts') of future sales, to be revised as real purchases do or do not take place. (Green 1991, 62-3)

Early-stage investments in firms with radically innovative technologies and/or business models are high-risk gambles and most fail; according to one Silicon Valley VC, a tolerance for seemingly bizarre ideas are accepted as a necessity: "if you want to go where the big wins are, be a little crazy ... Conventional wisdom leads to conventional returns" (quoted in Shapin 2008). Thus the growth in unicorn firms might be understood as an expansion in the regime of hope.

In Silicon Valley the promissory capitalism of start-up financing draws heavily on the rhetoric of disruption to signal a set of ideals and practices that resonate with the established Silicon Valley value system. As noted earlier, given Silicon Valley's reliance on high-tech industry and financial speculation as drivers of economic growth, the area is exceptional in its exemplification of postindustrial capitalism, but the Valley has also been home to a distinctive brand of neoliberal ideology that celebrates the region's culture of high-tech entrepreneurship. Two decades ago Barbrook and Cameron (1996) described the earliest manifestation of this belief system as the 'Californian ideology', a fusion of the counter-cultural radicalism of San Francisco with the hightech entrepreneurship of Silicon Valley, that

... promiscuously combines the freewheeling spirit of the hippies and the entrepreneurial zeal of the yuppies. This amalgamation of opposites has been achieved through a profound faith in the emancipatory potential of the new information technologies. (45)

This ideology redefined the political centre ground by drawing on ideas from the New Left and the New Right. The multiple strands and sources of this anti-statist ideology include the libertarian, free market individualism of Ayn Rand and a Schumpeterian-inspired cult of entrepreneurial innovation. The historic roots of the West Coast tech world in 1960s counterculture and the renegade romance of cyberpunk hacker culture has lent the corporate 
giants of the digital economy a patina of anti-establishment radicalism. Viewed in this historical perspective, the cult of disruption is simply a new twist on the Californian ideology. As Evgeny Mozorof (2013a), suggests:

Hiding beneath this glossy veneer of disruption-talk is the same old gospel of individualism, small government, and market fundamentalism that we associate with Randian characters. For Silicon Valley and its idols, innovation is the new selfishness.

Disruptive innovation as a theory of economic and technological change was developed by the Harvard business professor Clayten Christensen as a theory to explain how new entrants take over existing markets using new technologies and/or business models (Christensen 1997). ${ }^{\text {i The }}$ theory has become enormously popular (see table 2), but a number of scholars have suggested that it is profoundly flawed (Simons 2009), and that even the case studies cited by Christensen do not support his theory (King and Baatartogtokh 2015). For his part Christensen argues that his ideas have been misunderstood and misrepresented, not least in Silicon Valley where common parlance has dropped the word innovation and now just refers to disruption and disruptors. Using the example of the online taxi firm Uber, Christensen argues that “... too many people who speak of "disruption" ... use the term loosely to invoke the concept of innovation in support of whatever it is they wish to do" (Christensen, Raynor and McDonald 2015).

\section{Table 2}

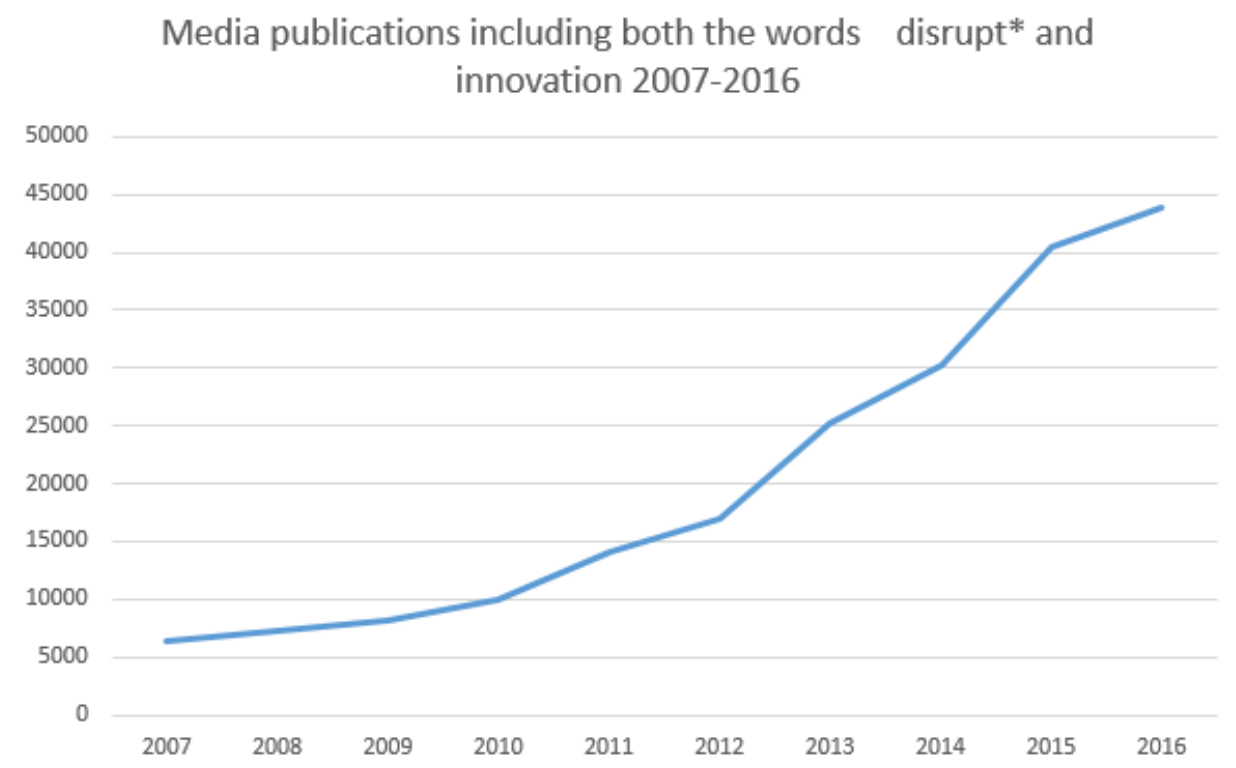

Source FACTIVA, search 13/12/2016

\footnotetext{
' The disruptors gain market entry not by offering a superior product but by exploiting the fact that incumbents in mature markets tend to focus on their most demanding and profitable customers, neglecting the needs of other parts of the market. Once that market has developed disruptors then move upmarket, targeting the incumbents' mainstream customers.
} 
The insight that disruptive innovation is now a signifier that has floated free of its original conceptual mooring is a starting point for this paper. In defining the Silicon Valley approach to disruption this paper suggests there are five key components:

1. A compelling vision of socially beneficial market transformation communicated by a passionate CEO

2. A belief in the transformative power of information technology (especially the internet)

3. Regulatory arbitrage as a form of competitive advantage, frequently defended as a means to deliver consumer value by disrupting entrenched market incumbents

4. The ambition for global growth and market dominance

5. A willingness to rapidly adapt business models in response to changing conditions

\section{3andme - the business of disruption}

\section{Vision - making the world a better place.}

In his discussions with Silicon Valley VCs, the historian Steven Shapin (2008) was told that start-up founders need more than a desire for wealth, because avarice alone will not fortify against the inevitable setbacks that entrepreneurs experience: "The guy who wants to do it for money? He's going to bail on you when the going gets tough ... You need people who want to change the world" (295). Gompers' 2016 survey of venture capitalists found that when they evaluate a start-up's management team, VCs rate passion as an important quality, and that this attribute is especially favoured by VCs in California.

The public pronouncements of 23andme's CEO Anne Wojcicki's establish her as exactly the kind of passionate, committed visionary that venture capitalists want to invest in. From the firm's launch the founders of 23andme presented themselves as disruptive agents of change seeking to challenge the biomedical establishment. Fast Company magazine named Anne Wojicki “America's Most Daring CEO." In 2015 she described herself as "A rebel fighting the system" (Pollack 2015). The concept of disruption was routinely invoked to signal the scale of the firm's ambitions. In 2012, a feature in Fortune magazine reported that "Wojicki uses the word disrupt a lot; and she has some big audacious hopes for her company..." (Benner 2012). In 2013 the firm was listed in the TV business news channel CNBC's inaugural Disruptor 50 list, a roll-call of the top private, venture-backed companies, "disrupting the status quo in ten traditional industries." The founders of 23andme wanted to transform healthcare by refocusing it on the goal of disease prevention to radically extend life expectancy. As Wojcicki said in 2013: "My goal isn't to just minimize the chance of getting sick. I want to live a healthy life at 100" (Brady 2013). For 23andme this emphasis on preventive healthcare meant that genetic risk assessment was at the heart of its technoscientific vision.

"The most important thing I want to know as a consumer is am I at risk of something? ...

Genetics is all about what you are at risk for, and the only way I can know how to prevent a disease is if I know what I am at risk for, and then I need to know what to do to try to prevent it ...." (Wojcicki 2011)

Wojicki presented the firm's mission to disrupt healthcare by a shift to preventing medicine as a reaction to the period she spent in the late 1990s working as a Wall Street analyst focused on the healthcare industry, where she became disenchanted with "watching how companies made money on sickness" (Wojcicki in Murphy 2013). 
... It made me frustrated that medicine didn't focus more on prevention ... decisions in our healthcare system are not being made in the best interests of the patient, but rather on optimising revenue. Bone-marrow transplants are profitable for doctors, for example, but checking someone out for melanoma doesn't make them any money. (Wojcicki in Teeman 2012)

Wojcicki's critique is underpinned by a neoliberal faith in the superior intelligence of the market and a very broad agenda of market-based reform based on the view that the fundamental problem with the healthcare system is that consumers do not pay directly for the services they receive. A 2012 profile in The Times reported that Wojicki did not believe in "the free NHS model" of healthcare: "I support a monetised system, but one that emphasises prevention and more freedom to choose" (Wojcicki in Teeman 2012). The logic that links preventive healthcare to consumer choice is consistently repeated in Wojicki's TED talks and media interviews: 1) prevention is the key to improved health; 2) doctors, drug firms and the rest of the medical establishment are not incentivised to prevent disease; 3) patients have no power because they do not pay directly for healthcare; 4) only empowered patients will shift the system towards prevention; 5) patients will be empowered when they hold the purse-strings.

"... you can't just trust that somebody is going to do the right thing for you. If you want to have the best health outcome, you need to be in charge of your health ... It's your job to manage your health" (Wojcicki in Pollack 2014)

Wojcicki's vision is neoliberal not only in its moral focus on individual responsibility, but in its faith in market-based solutions that undermine the traditional authority of clinicians.

\section{Digital disruption}

Alongside a vision of market-based consumerization, the founders of 23 andme promote the transformative power of the internet as a mechanism for collection, curation and dissemination of big data (see Saukko 2017). This vision of digital disruption is part of the origin myth of 23andme, recounted in countless news reports, interviews, and personal profiles and briefly summarised by this account from the Washington Post:

As a young analyst on Wall Street, Wojcicki had been frustrated by how a country with such wealth could fail to provide even the most basic medical needs to its citizens. By 2006, she had the connections to do something about it.

Wojcicki had moved to California to be with her then-boyfriend Brin and grew convinced that Silicon Valley, with its wonky algorithms and expertise in big data, could help.

For Wojcicki and her peers, disease wasn't an inevitable part of the human experience. It was more like a math problem. "I think this is something the Valley can solve for," Wojcicki said. (Eunjung Cha 2014)

The idea that human disease might be conquered by the algorithm logic of big data is consistent with Silicon Valley's longstanding support for the cause of technologically-enabled life extension; the region has been a base for research on cryogenics since the 1970s (McCray 2012). Subscribing to the view that more data is the key to better healthcare, 23andme's founders reproduce what Evgeny Morozov (2013b) describes as Silicon Valley's reigning ideologies: 'solutionism' and 'Internet-centrism'. 


\section{Regulatory arbitrage - Silicon Valley is from Mars, the FDA is from Venus}

The idea of digital disruption is inextricably linked to the third characteristic of Silicon Valley disruption: regulatory arbitrage. Dotcom disruptors like AirBnB and Uber exploit the potential for regulatory arbitrage offered by the ambiguous novelty of their market function - is Uber a taxi firm or a software business? Disruption is thus often bound up with a critique of government regulation and a logic of regulatory incommensurability. Disruptor firms suggest that since the way they operate is radically different to the practices of market incumbents, then existing regulations may be inappropriate, and serve only to protect the market incumbents from the full brunt of unfettered market competition. Disruptor firms shift tactically from flouting the law to lobbying for legislative change depending on the logic of local circumstance:

Lessons from regulated industries show that disuptors can topple the incumbents in these industries by first innovating outside of the reach of regulators; as the up-starts accumulate a sufficient number of customers, regulators cave ex post facto to the new reality in reaction to the innovator's success. (Horn 2016)

The practice of regulatory arbitrage might have multiple attractions for VC investors: to the extent that the $\mathrm{VC}$ community embraces neoliberalism, then deregulation is a fundamental tenet of their belief system; evading the costs of regulatory compliance provides a competitive advantage over market incumbents; and, the potential for regulatory arbitrage itself becomes a signal of the disruptive nature of a start-up's business model.

The potential for 23andme to exploit ambiguity about whether it was a software firm or a healthcare firm could have been attractive to investors hoping for an opportunity to work in the healthcare system without the added costs of regulatory compliance. A 2006 article in Business 2.0 (a magazine that aspired to be the trade journal of the New Economy) highlighted precisely this possibility in a feature that surveyed business opportunities in consumer healthcare such as the nascent consumer genomics sector. The article concluded with a list of recommendations for entrepeneurs, including the suggestion that they run their businesses on the internet in order to avoid unnecessary regulatory complications:

Stay clear of services that require you to spend a lot of quality time with the FDA. So consider dropping that plan for a high-tech hospital and think instead about a service that delivers hospital-quality health information to consumers, such as WebMD's. (Alsever et al 2006)

From the outset 23andme pursued just such a strategy of regulatory arbitrage. In a 2008 feature in Wired Anne Wojcicki stated that the genetic risk scores that they provided were not diagnostic:

"'It's simply your information,' she insists. In part, this distinction is to make sure the company doesn't run afoul of the Food and Drug Administration, which strictly regulates diagnostic testing for disease but has been slow to respond to the more transformational aspects of genomics. (Goetz 2008)

The FDA were not the first regulatory body to challenge this strategy. In the USA clinical laboratories are regulated under federal law by the Clinical Laboratory Improvements Amendments but some states such as California and New York enforce their own more stringent regulations. Soon after launching, consumer genomics firms including 23andme and Navigenics 
received warning letters from New York State officials. A 23andme spokesman responded by stating that the regulations did not apply to the firm because it was not offering medical tests: "'23andMe's services are not medical ... they are educational." (cited in Langreth and Herper 2008)

In the wake of the FDA's shutdown of 23andme's health reports, some pointed to the ideology of disruption as the source of a lax attitude to regulatory compliance. In October 2016 the cover story in the San Francisco Business Times was entitled 'Why are so many startups behaving badly, and can anything be done about it?' The story cited both Theranos and 23andme as examples of biotech start-ups failing in regulatory compliance, and quoted one venture capitalist who suggested that the logic of disruption might be a contributory factor:

“Some people may think that being a disruptor means you can break the law, but I don't ... In health care, where patient safety and security are paramount, it is a red flag when founders want to go at odds with the FDA." (Julia Papanek quoted in McDermid 2016) A report in the Financial Times commenting on the problems encountered by 23andme and Theranos also suggested that this was a culture clash between Silicon Valley start-ups focused on "the pace of disruption" and the established industry, committed to "a painstakingly slow, highly regulated approach" One investor described a "cultural mismatch" that necessitated better communication: "Both regulators and the companies need to work together to better understand each other" (Crow 2015). Wojcicki has indicated that the FDA is committed to finding a regulatory path for DTC genetics, but has also expressed frustration at a profound culture clash: "It's probably not going to be exactly what we wanted and it's going to take time. In Silicon Valley, you want things done instantly. It's not going to be that" (Hof 2014). The idea of a West Coast/East Coast culture clash between Silicon Valley and the FDA belies the obvious fact that there are many successful biotechnology firms in the Valley who have successfully navigated the FDA's regulatory pathways. The argument only makes sense if Silicon Valley is being used as a synonym for the tech sector. As Wojcicki indicates, much of the perceived cultural clash is about the pace that software firms operate at. Consider this Wojcicki quotation from 2014, discussing the use of 23andme's database as a research resource for academics and pharmaceutical firms:

We're in the beta phase. It's a challenging build because you want to answer a lot of questions and it's a lot of data, and you also have to protect privacy (Hof 2014).

That the development of 23andme's core asset could be considered as being in "beta phase" eight years after the firm was launched is indicative of the degree to which the firm operates with the software industry's development model of constant iteration and product refinement through beta testing with consumers. This approach was in evidence when the firm talked about its polygenic risk assessment scores. For instance, in 2008 Anne Wojcicki was cautious about the what they could offer at that time: "... the genetic profiles are in their preliminary stage and it's too early to be making predispositions and alarming people with the findings" (Lowe 2008). In 2010, Esther Dyson, an early investor and board member was still cautious: "... over time the product is going to be better, because over time, the data is going to be more meaningful" (Pollack 2010). 
This beta testing model was an important part of how 23andme responded to its critics - the firm's approach was to suggest that they were engaged in a long-term, iterative process of developing their service through dialogue with users and experts.

As we continue to respond to feedback from customers and scholars in the scientific, medical, and ELSI communities, 23andMe becomes as much a reflection of its users and critics as of the people at 23andMe (Hsu et al 2009).

Wojcicki invoked the same philosophy in explaining the firm's problems with the FDA:

When you try new things, you will make mistakes ... The best thing you can do is to understand how you quickly recover. (Hof 2014)

Wojcicki herself continued to imply that some of the regulatory challenges the firm presents arise from the fact it is a software business, at a time when 23andme was claiming to be fully committed to obtaining FDA approval:

The FDA said it plans to regulate software companies as medical devices. If you get your genome done, you can ship it off to Canada or China or other places in the world and get an interpretation. So how do you regulate information? That's one of the issues. I'm not sure you can hold it back. (Hof 2014).

One interpretation is that this quotation reveals the firm's continued ambivalence about the relative merits of regulatory arbitrage and regulatory compliance. An alternative reading is that it represents part of the firm's negotiating position: by 2014 23andme had moved into lobbying mode, with Wojcicki visiting the US Congress and the White House (Eunjung Cha 2014). The firm was not simply pursuing regulatory compliance but regulatory reform. In the last two years 23andme has gained FDA clearance for carrier testing for a range of monogenic diseases, and more recently for a number of genetic risk scores (see Curnutte 2017). The fact that FDA has provided a regulatory exemption for future genetic risk tests, allowing the firm to extend its service without prior FDA clearance, suggests that 23andme's recent Washington lobbying activity may have been effective.

\section{Market dominance}

As, the economist Ann Pettifor (2015) has remarked, firms like AirBnB and Uber have "monopolistic aspirations". The growth of such firms is driven by network effects that act as a barrier to market entry. Characterizing the rise of such dotcom disruptors as a new era of "platform capitalism", Srnicek argues that "a tendency towards monopolization is built into the DNA of platforms" (Srnicek 2017). The generous VC funding offered to such firms is spurred by the hope of achieving the kind of monopoly or market dominance that has characterised the most successful dotcom firms like Google and Amazon. Peter Thiel, a leading Silicon Valley VC investor, is candid about the commercial allure of monopolies:

... capitalism and competition are opposites. Capitalism is premised on the accumulation of capital, but under perfect competition, all profits get competed away. The lesson for entrepreneurs is clear: If you want to create and capture lasting value, don't build an undifferentiated commodity business. (Thiel 2014)

One VC investor quoted in a report on the lean investment climate for genomics firms in 2012 suggested this mindset influenced how such firms are evaluated: 
... to get a syndicate of investors willing to open their wallets to one particular company, it needs to demonstrate that it essentially has few, if any, competitors ... companies today must present products with disruptive potential, rather than incremental improvements to existing technology, in order to get noticed. (Fong 2012)

Here we see how VC valuation practices treat disruption as a synonym for market dominance or even outright monopoly. To what extent was the interlinkage of disruption and the restriction of competition relevant in the case of 23andme? New Enterprise Associates, the first VC firm to invest in 23andme, is represented on the firm's board by Patrick Chung. In 2013 Chung stated that 23andme's goal was to become "the Google of personalised health care" (Murphy 2013), a clear signal that some of the firm's early investors were motivated by the idea of market dominance. Anne Wojcicki was expressing such ambitions from the outset:" "We'd like to reach 98\% of the world, that is our goal"(cited in Lowe 2008). In 2014, she was still talking about a global genomic monopoly, this time in relation to 23 andme's role in genetic research:

There's still a lot of redundancy in this industry because of competition. Part of my goal is to eliminate some of that commodity competition ... Traditionally when you talk to people who have Parkinson's or Alzheimer's, they'll talk about how they're in five or six studies and they've been sequenced by each study. That's just fat in the system. Just have a single data set that then you can share. You can make the entire system more efficient ... We have so much information about humanity that we almost become the ultimate epidemiological company with genetic information that can be used for research. (Hof 2014)

23andme's relationship to its commercial competitors was briefly a topic of controversy in 2013 when Ruslan Dorfman (2013), CEO of a rival firm, accused 23andme of wanting to get "a stranglehold on the market" (785). 23andme had dropped the price of its testing service to $\$ 99$ in late 2012 following a funding round in which it had raised \$50M. Dorfman accused of 23andme of using this money to finance a strategy of "price-dumping" - the firm was selling its test as a loss-leader in the hope of generating revenue from gene patents. Other commentators agreed that 23andme was now using its test as a loss leader, but they suggested that the firm was focused on genetic research as its principal new revenue stream.

\section{Pivoting to profit?}

This uncertainty about the firm's business model brings us to the final of our five characteristics of disruptor firms: the willingness to rapidly adapt business models in the light of changing circumstances. 23andme has been forced to adapt in response to FDA intervention and because of longstanding doubts about its commercial viability. When 23andme launched, the journalist David Hamilton suggested the firm would not to be able to create a sustainable business from consumer sales alone because the margins were too thin (Hamilton 2007). A 2010 article by Andrew Pollack reported that market uptake was slow - 23andme had only 35,00 customers and at least $25 \%$ of those had received the test for free or at the discount price of $\$ 25$ (Pollack 2010). Even within the firm uncertainty about the business model has been an issue since its launch. In 2007 Anne Wojcicki stated:

It's really too early to specify how we might monetize and derive value from the information we're aggregating. We've thought about a lot of different ways to monetize it, but we're not ready to talk about them. (Wojcicki in Hamilton 2007) 
Six years after launch in September 2013 the firm's new President Andy Page was still saying the business model was a work in progress: "The most important thing right now is scale," says Page. "Once we get that, then the business model will follow" (Brady 2013).

23andme has two core assets: its expertise in curating and communicating genomic science, and its growing database of customers who are willing to allow their data to be used for genomic research and/or to participate actively in research projects (by providing further data). Since its inception the firm has developed multiple revenue streams: customer sales, federal research grants and contract research for pharmaceutical firms. Following the FDA's regulatory intervention, there was a growth in research activity as 23andme received multiple research grants from NIH and industry investment from pharmaceutical firms seeking to exploit their database. In 2015 23andme struck deals with Genentech and Pfizer providing them with access to the firm's database in return for "upfront payments and a cut of revenue from new drugs development" (Bercovici 2015). 23andme subsequently established its own drug development unit.

These developments were followed by a new financing round in which the firm raised $\$ 115 \mathrm{M}$, nearly as much as the cumulative total it raised in the first four financing rounds. It was in this investment round that 23 andme was valued at just over $\$ 1$ Billion, and the firm joined the growing band of Silicon Valley unicorns. Yet when the firm announced its intentions to move into drug development not everyone was convinced. Andrew Pollack at the New York Times cited the failures of older genomics firms like Celera and deCODE which had attempted to straddle diagnostics and drug development but failed (Pollack 2015). Furthermore, there seemed to be continued confusion within 23andme about its business model: Anne Wojcicki stated that the firm's main revenue stream would be R\&D for pharma firms (Anonymous 2013) but Andy Page stated "We always were and always will be a consumer company first, but doing research is a close second." (quoted in Lash 2015) According to one industry executive, the tension between the two business models continues to slow progress on FDA approval: "23andme have great research scientists, but they are terrible at product development." (Anonymous 2017)

\section{Discussion - between hope and truth in unicorn valley}

The case of 23andme sheds new light on the practice of promissory capitalism and the "complex entanglements of hope and truth at the different stages of company development and market formation." (Martin 2015, 439). Martin's regime of truth has, in effect, three evaluative domains in which hopes are tested: the consumer market, the regulatory regime and the public stock market.

With regard to the consumer market, the hope articulated by 23andme was that within five to ten years "it will be standard for individuals to have access to their genetic information" (Wojcicki quoted in Dubner 2009). In October 2015 23andme declined to reveal customer numbers to the New York Times (Pollack 2015), but according to Anthony Regalado (2016) the firm had 1.2 million customers by June 2016. Given this failure to establish consumer genomics as a 'standard' consumer good routinely accessed by a significant portion of the population, the firm's quest for commercial viability has pivoted towards greater emphasis on the business-tobusiness market of pharmaceutical R\&D services. Its subsequent pivot towards drug development has, according to the CEO, only served to further defer the goal of profitability 
(Pollack 2015). In effect the firm has moved the evaluative goalposts, placing it in a liminal position between the regime of hope and the regime of truth.

23andme's promise to disrupt healthcare by a shift towards preventive medicine is undermined by this change in business models. Anne Wojcicki continues to offer a social critique of the ways in which financial incentives in healthcare are skewed to treatment not prevention, yet her firm's business model is now based on providing pharmaceutical R\&D services and developing its own novel therapeutics. This apparent disjuncture offers an insight into how disruption functions as rhetorical strategy across separate evaluative principles. 23andme's investors want the firm's CEO to communicate passionately her compelling vision of the social value of consumer genomics, and they need the firm establish a sustainable business model that will generate a significant return on investment. Since these are two separate evaluative principles, then contradictions between them are not necessarily matters of concern for investors.

The encounter with the FDA was also part of 23andme's partial transition to the regime of truth, challenging its disruptor strategy of regulatory arbitrage by forcing closure on the ambiguity about whether the firm was simply an internet-based research business, generating its own data and sharing the fruits of the broader genomic research enterprise with the public, or a consumer healthcare service. The bolder the firm's claims that genetic risk assessment was a preventive health strategy that could transform medicine, the harder it became to argue that it should not be regulated as a healthcare product. Such was the logic of the FDA (2013), which drew attention to the gradual expansion of 23andme's marketing claims in the warning letter that led to closure of the firm's health-related testing service in the USA in 2013.

The disruptor practice of regulatory arbitrage has been abandoned in favour of a dual strategy of compliance and lobbying for regulatory reform. The recent success of this strategy notwithstanding, it should be noted that the risk gene tests which have been FDA-approved are all for single genes; the polygenic risk scores that were a core part of 23andme's health testing service, but that had attracted much scientific criticism, remain firmly in the regime of hope. The reasons for the regulatory exemption for future risk tests that accompanied the recent FDA clearance are unclear, but it may demonstrate the value of the established disruptor tactic of switching from regulatory arbitrage to lobbying for regulatory reform. Perhaps the exemption also signals an accommodation between the software industry's beta testing mode of iterative, flexible innovation and the more linear, sequential approach to product development enforced by the FDA, thus demonstrating Stark's contention that successful entrepreneurship entails harnessing the creative friction generated by the "rivalry of evaluative principles" (6).

The FDA's 2013 action against 23andme raises important issues about corporate governance in unicorn firms. Had the firm been public at the time when FDA shut down its health reports in November 2013, its share price would have plummeted and Anne Wojcicki would likely have come under intense pressure to resign as CEO. Further pressure might have come from investor scrutiny of the firm's commercial performance - in her 2015 interview with the New York Times Wojcicki revealed that the firm was not yet profitable (Pollack 2015). At this point the firm had been operating for eight years and had raised $\$ 240 \mathrm{M}$ in VC finance. In the traditional trajectory of a diagnostics start-up 23andme's investors would have already pushed for a liquidity event to generate a return on their investment, either through acquisition by a larger firm or via an IPO. Either option would have meant that the firm would have been subject to intense external 
scrutiny of its assets, business model, and management team. Flotation would have opened the firm to publication of quarterly financial reports that would have been subject to expert assessment by stock market analysts.

23andme has been able to attract such huge investments but still remain a private firm because of the massive increase in private capital available for start-ups in Silicon Valley. Marc Andressen, one of Silicon Valley's leading venture capitalists, was reported in the New York Times describing the stark divergence between how investors now behave towards the chief executives of public firms and private firms: "'They tell the public C.E.O., 'Give us the money back this quarter,' and they tell the private C.E.O., 'No problem, go for 10 years' "(Manjoo 2015). It is perhaps unsurprising that Wojcicki has publicly stated that she wishes to keep the firm private for the time being (Wojcicki 2016).

How does the growth in private capital affect the relationship between regimes of hope and truth in the bioeconomy? There is now much discussion about whether rapid growth in the number of unicorn firms signals that Silicon Valley has become embroiled in another investment bubble. Industry analysts report that some unicorn firms are stuck in pre-IPO because there is "a large unresolved disparity between public and private market valuations" of the firms' commercial worth (Renaissance Capital 2015). Gompers' 2016 survey of venture capitalists found that $91 \%$ thought that unicorns were over-valued, an opinion shared by those who had invested in unicorns and those who had not.

To return to Paul Martin's model, it seems that by reducing firms' reliance on public flotation as a source of investment finance, the era of unicorn finance has expanded the liminal space between the regimes of hope and truth. That liminal space is not confined geographically to Silicon Valley, but the region's abundant private capital and its distinctive style of disruptive entrepreneurship are critical components in this new mode of promissory capitalism. Understanding how this regime of accumulation functions requires attention to the multiple evaluative principles at play, and the ways in which they intersect. Given the growing concerns that the rise in unicorn firms signals an unsustainable and potentially destructive investment bubble, there is a pressing need for further scrutiny of the rationalities that underpin venture capital valuation processes.

This paper has argued that research on the bioeconomy should pay greater attention to processes of geographical differentiation. Future work might usefully interrogate these dynamics in comparative perspective, broadening out to encompass other high-tech clusters in the USA, Europe and Asia-Pacific. At the sectoral level, there is considerable scope for more explicit comparison of diagnostics and therapeutics firms. Finally, this paper suggests that a fruitful area for further research in the sociology of expectations would be the role of charismatic leadership in start-up firms. Such research might examine the performativity of corporate values and their embodiment in the person of the CEO, the media's role in the promotion of entrepreneur as celebrity, and the role these business leaders play in managing their firms' transition from the regime of hope to the regime of truth.

\section{References:}


23andme. 2008. “TIME Magazine Names 23andMe's Personal Genome Service 2008 Invention of the Year." Press release, October 30 https://mediacenter.23andme.com/press-releases/timemagazine-names-23andmes-personal-genome-service-2008-invention-of-the-year/

Alsever, J., S. Durst, J. Borzo, and S. S. R. Datta. 2006. “The Patient Knows Best.” Business 2.0, November 9.

http://money.cnn.com/magazines/business2/business2_archive/2006/10/01/8387104/index .htm

Anonymous. 2013. "How 23andMe Disrupts Health Care With DNA." BioBox Bloomberg, November 26 https://www.bloomberg.com/news/videos/b/ee8c5651-9fdc-4fea-bf01$2 \mathrm{~d} 9 \mathrm{e} 574 \mathrm{fc} 75 \mathrm{~d}$

Anonymous, 2017. Personal communication with US diagnostics industry executive, March 2017.

Barbrook, R. and Cameron A. 1996. "The Californian Ideology.” Science as Culture 6 (1): 44-72.

Benner, K. 2012. "23andme Wants to Change the Face of Health Care." Fortune, December.

Bercovici, J. 2015. "The Billion-Dollar Company That Not Even the Feds Could Stop." Inc., October. https://www.inc.com/magazine/201510/jeff-bercovici/the-dna-whisperer.html Birch, K., and D. Tyfield. 2012. "Theorizing the Bioeconomy: Biovalue, Biocapital, Bioeconomics or... What?" Science, Technology, \& Human Values 38 (3): 299-327.

doi:10.1177/0162243912442398

Boltanski L., and L. Thévenot. 1991. On Justification. Economies of Worth. Princeton, NJ: Princeton University Press.

Brady, D. 2013. "23andme Wants to Take Its Tests Mass-Market." Bloomberg, September 30. https://www.bloomberg.com/news/articles/2013-09-30/23andme-wants-to-take-its-dnatests-mass-market

Casper, S. 2006. "Exporting the Silicon Valley to Europe: How Useful Is Comparative Institutional Theory?" In Innovation, Science, and Institutional Change: A Research Handbook, edited by Jerald Hage and Marius Meeus, 483-504. Oxford: Oxford University Press.

Christensen, C. M. The Innovator's Dilemma: When New Technologies Cause Great Firms to Fail. Boston, MA: Harvard Business School Press.

Christensen, C. M., M. Raynor and R. McDonald. 2015. "What Is Disruptive Innovation?" Harvard Business Review, December. https://hbr.org/2015/12/what-is-disruptive-innovation Crow, D. 2015. “Theranos Exemplifies Clash of New Versus Old In-Vitro Test Models." Financial Times, December 15.

Curnutte, M. 2017. "Regulatory Controls for Direct-to-Consumer Genetic Tests: A Case Study on How the FDA Exercised its Authority." New Genetics and Society. doi:10.1080/14636778. 2017.1354690.

Dorfman, R. 2013. "Falling prices and unfair competition in consumer genomics." Nature Biotechnology, 31(9), 785-6. 
Dubner, J. 2009. "Genetics Entrepreneur Anne Wojcicki Answers Your Questions." Freakonomics Blog, August 12. http://freakonomics.com/2009/08/12/genetics-entrepreneur-anne-wojcickianswers-your-questions /

Eunjung Cha, A. 2014. "23andMe Co-Founder Anne Wojcicki's Washington Charm Offensive" Washington Post, June 27.

FDA. 2013. Warning Letter to Anne Wojcicki, 23andme. Department of Health and Human Services, November 22.

https://www.fda.gov/iceci/enforcementactions/warningletters/2013/ucm376296.htm

Fong, T. 2012. Difficult VC Funding Market Extends to 'Omics, MDx. GenomeWeb Aug 20.

Goetz, T. 2007. "23andme Will Decode Your DNA for $\$ 1,000$. Welcome to the Age of Genomics." Wired, November 17.

Gompers, P. W. Gornall, S. Kaplan, and I. Strebulaev. 2016. "How do venture capitalists make decisions?” Stanford University Graduate School of Business Research Paper No. 16-33.

Green, K. 1991. "Shaping Technologies and Shaping Markets: Creating Demand for Biotechnology." Technology Analysis \& Strategic Management 3(1): 57-76.

Gupta, A,, and H. Wang. 2016. "The Reason Silicon Valley Beat Out Boston for VC Dominance." Harvard Business Review, November 16. https://hbr.org/2016/11/the-reason-silicon-valleybeat-out-boston-for-vc-dominance

Hamilton, D. 2007. "23andme: Will the Personal-Genomics Company Need Big Pharma to Make Money?" VenutreBeat, November 19.

Helmreich, S. 2008. “Species of biocapital." Science as Culture 17(4): 463-478.

Hof, R. 2014. "We Are Going For Change': A Conversation With 23andMe CEO Anne Wojcicki." Forbes, August 15. http://www.forbes.com/sites/roberthof/2014/08/15/we-are-going-forchange-a-conversation-with-23andme-ceo-anne-wojcicki/\#5af96b275477

Hogarth, S., and Salter, B. 2010. "Regenerative medicine in Europe: global competition and innovation governance." Regenerative Medicine 5(6): 971-985.

Horn, M. 2016. "Uber, Disruptive Innovation, and Regulated Markets." Christensen Institute Blog, June 16. http://www.christenseninstitute.org/blog/uber-disruptive-innovation-and-regulatedmarkets/

Hsu, A. R., J. L. Mountain, A. Wojcicki, and L. Avey. 2009. "A Pragmatic Consideration of Ethical Issues Relating to Personal Genomics." The American Journal of Bioethics 9 (6-7): 1-2. doi:10.1080/15265160902966795.

Keegan, K. 2008. Biotechnology Valuation: An Introductory guide. Wiley: Chichester King, A., and B. Baatartogtokh. 2015. "How Useful Is the Theory of Disruptive Innovation?" MIT Sloan Management Review, September. http://sloanreview.mit.edu/article/how-useful-is-thetheory-of-disruptive-innovation/ 
Langreth, R., and M. Herper. 2008. "States Crack Down on Online Gene Tests." Forbes, April 18. http://www.forbes.com/2008/04/17/genes-regulation-testing-biz-

cx_mh_bl_0418genes_print.html

Lash, A. 2015. "23andme Adds On: More About The Gene-Test Maker's Drug R\&D Ambitions." Xconomy, March 12. http://www.xconomy.com/san-francisco/2015/03/12/23andme-adds-onmore-about-the-gene-test-makers-drug-rd-ambitions/?utm_source=related-

content\&utm_medium=link\&utm_campaign=related-content

Lazonick, W, and O. Tulum. 2011. "US biopharmaceutical finance and the sustainability of the biotech business model. Research Policy 40: 1170-1187.

Lowe, F. 2008. “Google Wife Targets World DNA Domination.” Daily Telegraph, January 25.

Manjoo, F. 2015. "As More Tech Start-Ups Stay Private, So Does the Money." New York Times, July 1.

Martin, P. 2015. "Commercialising Neurofutures: Promissory Economies, Value Creation and the Making of a New Industry." BioSocieties 10(4):422-443. doi:10.1057/biosoc.2014.40.

McCray, W P. 2012. “California Dreamin': Visioneering the Technological Future.” in Minds and Matters: Technology in California and the West, edited by Volker Janssen, 347-

378. California: University of California Press.

McDermid, R. 2016. "Why Are So Many Startups Behaving Badly, and Can Anything Be Done About It?" San Francisco Business Times, October 6.

http://www.bizjournals.com/sanfrancisco/news/2016/10/06/startup-ethics-ipo-zenefitstheranos-lending-club.html

Mihaescu, R., M. Van Hoek, E. J. G. Sijbrands, A. Uitterlinden, J. C. M. Witteman, A. Hofman, C. M. Van Duijn, and A. C. J. W. Janssens. 2009. "Evaluation of Risk Prediction Updates from Commercial Genome-Wide Scans." Genet Med 11 (8): 588-94.

Mirowski, P. 2011. Science-Mart: Privatizing American Science. Cambridge, MA: Harvard University Press.

Moreira, T., and P. Palladino. 2005. "Between Truth and Hope: On Parkinson's Disease, Neurotransplantation and the Production of the 'Self." History of the Human Sciences 18 (3): $55-82$.

Morozov, E. 2013a. “The Meme Hustler: Tim O’Reilly's Crazy Talk.” The Baffler, April. http://thebaffler.com/salvos/the-meme-hustler

Morozov, E. 2013b. To save Everything Click Here. New York: Public Affairs, NY.

Murphy, E. 2013. “Inside 23andme Founder Anne Wojcicki’s \$99 DNA Revolution.” Fast Company, October.

Pettifor, A. 2015. Is capitalism 'mutating' into an infotech utopia? Open Economy 6 November https://www.opendemocracy.net/ann-pettifor/is-capitalism-mutating-into-infotech-utopia Pollack, A. 2010. “Gene-Testing Companies: Too Little Too Soon for Success." International Herald Tribune, March 20. 
Pollack, A. 2010. “Outlook Uncertain.” New York Times, March 20.

Pollack, A. 2015. "23andMe Will Resume Giving Users Health Data.” New York Times, October 21.

Pollack, N. 2014. “23andme Wants to Reveal Health Risks Using Your DNA.” Wired, December 2.

Rao, L. 2009. "All in the Family: Sergey Brin Loans 23andme $\$ 10$ Million and Google Ponies up \$2.6 Million.” Techcrunch, June 18. https://techcrunch.com/2009/06/18/all-in-the-familysergeybrin-loans-23andme-10-million-and-google-ponies-up-26-million/.

Regalado, A. 2016. “23andMe Sells Data for Drug Search.” MIT Technology Review June 21. https://www.technologyreview.com/s/601506/23andme-sells-data-for-drug-search/.

Renaissance Capital. 2015. "2015 US IP annual review.”

http://www.renaissancecapital.com/news/renaissance-capitals-2015-us-ipo-annual-review37648.html

Saukko, P. 2017. "Shifting Metaphors in Direct-to-Consumer Genetic Testing: From Genes as Information to Genes as Big Data." New Genetics and Society.

doi:10.1080/14636778.2017.1354691.

Sayer, A. 1995. Radical Political Economy: a Critique. Oxford: Blackwell.

Sayer, A. 2004. “Moral Economy.” Department of Sociology, Lancaster University. http://www.comp.lancs.ac.uk/sociology/papers/sayer-moral-economy.pdf

Shapin, S. 2008. The Scientific Life: A Moral History of a Late Modern Vocation. Chicago, Ill: University of Chicago Press.

SharesPost. 2016. "Zero to One Billion: Demistifying the Unicorn." SharesPost. Accessed May 9 2017. http://sharespost.com/insights/research-reports/zero-to-one-billion-landing/

Sheppard,E. 2013. "Rethinking Capitalism from a Geographical Perspective." Archives of the Association of Economic Geographers 59(4): 394-418.

Simons, K. 2009. “Two Roads to Riches: The (In)frequency of Strongly Disruptive Technological Change” Department of Economics, Rensselaer Polytechnic Institute, November 9.

http://homepages.rpi.edu/ simonk/pdf/tworoads.pdf

Srnicek, N. 2017. Platform Capitalism. Cambridge: Polity Press.

Stark, D. 2009. The Sense of Dissonance: Accounts of Worth in Economic life. Princeton: Princeton University Press.

Teeman, T. 2012 “'He Cooks. I Clean'; The Simple Life of the Google Power Couple.” The Times, February 4.

Tellis, G. 2016. "Startup Index of Nations, Cities: Startups Worth \$1 Billion or More (“Unicorns")." Center for Global Innovation, USC Marshall School of Business. https://www.marshall.usc.edu/sites/default/files/PDF/Unicorn-Index-Report-GT17.pdf Thiel, P. 2014. “Competition Is For Losers.” Wall Street Journal, September 12. Wojcicki, A. 2016. Interview by Kara Swisher, Recode Decode, podcast audio, April 4. http://www.recode.net/2016/4/4/11585828/23andme-anne-wojcicki-genomics-theranosalex-rodriguez 
Wojicki, A. 2011. “A Conversation With Anne Wojcicki." Web2.0 Summit, 19 October. https://www.youtube.com/watch?v=hYs85Q13Trk 